\title{
Selective inhibitors of the osteoblast proteasome stimulate bone formation in vivo and in vitro
}

\author{
I.R. Garrett, ${ }^{1}$ D. Chen, ${ }^{1,2}$ G. Gutierrez, ${ }^{1}$ M. Zhao, ${ }^{1,2}$ A. Escobedo, ${ }^{1}$ G. Rossini, ${ }^{1}$ S.E. Harris,${ }^{3}$ \\ W. Gallwitz, ${ }^{1}$ K.B. Kim,${ }^{4}$ S. Hu, ${ }^{4}$ C.M. Crews ${ }^{4}$ and G.R. Mundy ${ }^{1,2}$ \\ ${ }^{1}$ OsteoScreen Inc., San Antonio, Texas, USA \\ ${ }^{2}$ University of Texas Health Science Center at San Antonio, San Antonio, Texas, USA \\ ${ }^{3}$ University of Missouri-Kansas City, School of Dentistry, Kansas City, Missouri, USA \\ ${ }^{4}$ Yale University, New Haven, Connecticut, USA
}

\begin{abstract}
We have found that the ubiquitin-proteasome pathway exerts exquisite control of osteoblast differentiation and bone formation in vitro and in vivo in rodents. Structurally different inhibitors that bind to specific catalytic $\beta$ subunits of the $20 \mathrm{~S}$ proteasome stimulated bone formation in bone organ cultures in concentrations as low as $10 \mathrm{nM}$. When administered systemically to mice, the proteasome inhibitors epoxomicin and proteasome inhibitor- 1 increased bone volume and bone formation rates over $70 \%$ after only 5 days of treatment. Since the ubiquitin-proteasome pathway has been shown to modulate expression of the Drosophila homologue of the bone morphogenetic protein-2 and -4 (BMP-2 and BMP-4) genes, we examined the effects of noggin, an endogenous inhibitor of BMP- 2 and BMP-4 on bone formation stimulated by these compounds and found that it was abrogated. These compounds increased BMP-2 but not BMP-4 or BMP- 6 mRNA expression in osteoblastic cells, suggesting that BMP-2 was responsible for the observed bone formation that was inhibited by noggin. We show proteasome inhibitors regulate BMP-2 gene expression at least in part through inhibiting the proteolytic processing of Gli3 protein. Our results suggest that the ubiquitin-proteasome machinery regulates osteoblast differentiation and bone formation and that inhibition of specific components of this system may be useful therapeutically in common diseases of bone loss.
\end{abstract}

J. Clin. Invest. 111:1771-1782 (2003). doi:10.1172/JCI200316198.

\section{Introduction}

The mechanisms by which bone formation is regulated during physiological bone remodeling is the subject of intense investigation, since enhancement of bone formation is desirable for adequate treatment of all of the common diseases of bone loss. Bone formation is regulated by growth regulatory factors that are expressed by bone cells, incorporated into the bone matrix, and released in active form when bone resorbs (1-3). As a

Received for publication June 14, 2002, and accepted in revised form March 25, 2003.

Address correspondence to: I.R. Garrett, OsteoScreen Inc., 2040 Babcock Road, Suite 201, San Antonio, Texas 78229, USA. Phone: (210) 614-0770; Fax: (210) 614-0797;

E-mail: garrett@osteoscreen.com.

I.R. Garrett and D. Chen contributed equally to this work.

Conflict of interest: I.R. Garrett, D. Chen, G. Gutierrez, M. Zhao, A. Escobedo, G. Rossini, and W. Gallwitz are all employees of and hold stock in OsteoScreen Inc. S.E. Harris, C.M. Crews, and G.R. Mundy all hold stock in OsteoScreen Inc.

Nonstandard abbreviations used: bone morphogenetic protein-2 (BMP-2); proteasome inhibitor-1 (PS1); $N$-tosyl-Lys chloromethyl ketone (TLCK); $N$-tosyl-Phe chloromethyl ketone (TPCK); $N$-acetyl-L-leucyl-L-leucyl-L-methioninal (ALLM); [2S,3S]-transepoxysuccinyl-L-leucylamido-3-methylbutane ethyl ester (EST) 1-pyrrolidinecarbodithioic acid (PDTC); 2-benzylamino-1,4napthoquinone (PPM-18); parathyroid hormone (PTH); bone formation rate (BFR); mineral apposition rate (MAR); fetal rat calvariae (FRC); human BMP-2 (hBMP-2); full-length Gli3 (FL-Gli3); truncated Gli3 (trGli3); $\beta$-galactosidase ( $\beta$-gal); 3-isobutyl-1-methylxanthine (IBMX); TBS plus 1\% Tween 20 (TBS-T); Cubitus interruptus (Ci); alkaline phosphatase (ALP). consequence, osteoblast proliferation and differentiation are enhanced, and a mineralized bone matrix is formed. The precise molecular mechanisms by which bone formation is controlled or how the process can be manipulated therapeutically remain unclear, however. The ubiquitin-proteasomal pathway is recognized as the major intracellular mechanism for degradation of many short-lived proteins (4-6). By this means, the proteasomal mechanism can regulate expression of important genes such as cell cycle regulators and transcription factors. Here, we show that the chymotryptic component of the proteasome is an important regulatory mediator of osteoblast differentiation and bone formation. Different inhibitors of the proteasome increase bone formation in vitro and in vivo, correlating closely with their effects to increase bone morphogenetic protein-2 (BMP-2) gene expression.

\section{Methods}

Compounds. Epoxomicin (7) and eponemycin were synthesized as described previously (8). YU101 (ac-hFLFLepoxide) was synthesized as described previously (9). Proteasome inhibitor-1 (PS1), MG132 (carbobenzyloxyL-leucyl-L-leucyl-L-leucinal), lactacystin, MG115 (carbobenzyloxy-L-leucyl-L-leucyl-L-norvalinal), ALLN ( $N$ acetyl-L-leucyl-L-leucyl-norleucinal), TLCK ( $N$-tosyl-Lys chloromethyl ketone), TPCK ( $N$-tosyl-Phe chloromethyl ketone), ALLM ( $N$-acetyl-L-leucyl-L-leucyl-L-methioninal), EST ([2S,3S]-trans-epoxysuccinyl-L-leucylamido- 
3-methylbutane ethyl ester), PDTC (1-pyrrolidinecarbodithioic acid), PPM-18 (2-benzylamino-1,4-napthoquinone), and Bay 11-7082 were purchased from CalBiochem-Novabiochem (La Jolla, California, USA). MG262 (N-benzyloxycarbonyl-L-leucyl-L-leucyl-L-leucyl boronic acid) ([E]3-[(4-methylphenyl)sulfonyl]-2-propenenitrile) was purchased from AFFINITI Research Products Ltd. (Exeter, United Kingdom). Mouse noggin/Fc chimera was purchased from R\&D Systems Inc. (Stillwater, Minnesota, USA).

Organ cultures of calvarial bones. The technique for studying organ cultures of neonatal murine calvarial bones has been described in detail previously $(10,11)$. The bones were removed from the calvariae of 4-day-old ICR Swiss mice and then cultured in Biggers, Gwatkins, Judah media with Fitton-Jackson modification with $0.1 \%$ BSA for 72 hours, together with test compounds. Following these treatments, the calvariae were fixed for 24 hours in 10\% phosphate-buffered formalin and then decalcified in $14 \%$ EDTA overnight. The calvariae were then embedded in paraffin, and $4-\mu \mathrm{m}$ sections were cut and stained by hematoxylin and eosin.

The effects on bone formation were evaluated by histomorphometric assessment using a Nikon E400 microscope attached to an Optronics 3 chip CCD color video camera. Images of the sectioned calvariae were captured at $\times 20$ objective magnification using a Pro-Series 128 Capture Kit frame-grabber board. Each captured image was then stored for future reference, and the area of new bone formation, expressed as new bone area (square millimeters $\times 10^{-3}$ ), and the number of bone-lining cells, expressed as cells per $0.3 \mathrm{~mm}$ bone, were measured using an image-analysis software, Image-Pro Plus (Media Cybernetics, Silver Spring, Maryland, USA).

Local effects on bone formation. To perform these experiments, we injected compounds into the subcutaneous tissue over the calvariae of normal mice using a technique described previously $(11,12)$. Five-week-old Swiss ICR white mice were injected three times a day for 5 days with vehicle alone, epoxomicin, or PS1 over the right side of the calvarium. Mice were euthanized on day 22, and calvariae were removed for histomorphometric analysis.

Systemic effects on bone formation. These experiments were performed using 5-week-old Swiss ICR white mice. The mice $(n=10)$ were treated with parathyroid hormone (PTH), epoxomicin, or PS1 for 5 days and sacrificed 16 days later. All animals were treated with tetracycline $(15 \mathrm{mg} / \mathrm{kg}) 13$ days before sacrifice and calcein green $(20 \mathrm{mg} / \mathrm{kg}) 3$ days before sacrifice to deposit double-fluorochrome labels on active boneforming surfaces. The tibiae were removed, freed from soft tissues, and fixed for 72 hours in 10\% phosphatebuffered formalin. The left tibiae were decalcified in $14 \%$ EDTA, pH 7.2, for 3 weeks, embedded in paraffin, cut in cross-sections $4 \mu \mathrm{m}$ thick, and stained by hematoxylin and eosin or by van Giesen stain. Images were captured and quantitated using a video camera mounted onto a Nikon E-400 microscope. Data were analyzed (bone volume measurements) using an image-analysis software, Image-Pro Plus (Media Cybernetics). The right tibia was fixed in $70 \%$ ethanol, embedded in plastic (methyl methacrylate), and sections ( $8 \mu \mathrm{m}$ thick) were prepared for histomorphometric analysis. Dynamic measurements were obtained using a camera lucida attachment to trace various bone parameters into a digitalizing tablet. Data were processed using a bone histomorphometry system, Osteomeasure (Osteometrics Inc., Atlanta, Georgia, USA). Trabecular bone volume was assessed in decalcified sections and bone formation rates (BFRs) and mineral apposition rates (MARs) were measured in plastic-embedded sections. The area measured was 2.5 $\mathrm{mm}^{2}, 0.5 \mathrm{~mm}$ below the growth plate to exclude the primary spongiosa. Bone volume was expressed as the percentage of bone volume in the area measured. MAR was the mean interlabel distance divided by the time interval (days) between the two fluorochromes administered. The surface referent/BFR was expressed as cubed micrometers per square micrometer per day.

Cell culture. MG63, 2T3 murine osteoblast precursor cells, Hu09 human osteoblastic cells, and fetal rat calvariae (FRC) primary osteoblasts were cultured with $\alpha$-MEM. All the media were purchased from SigmaAldrich (St. Louis, Missouri, USA) and supplemented with $10 \%$ FCS. For Northern blot experiments, MG63 and FRC cells were plated in T-150 flasks at density of $2 \times 10^{6}$ cells per flask for RNA extraction. For the luciferase assay, $2 \mathrm{~T} 3$ cells were plated in 24-well culture plates at a density of $2 \times 10^{4}$ cells/well. For the BMP-2 ELISA, Hu09 cells were plated in 96-well culture plates at the density of $10^{4}$ cells/well.

Luciferase assay. The $2 \mathrm{~T} 3$ cells were stably transfected with the murine BMP-2 promoter $(-2712 /+165)$ linked to firefly luciferase cDNA (13). The cells were plated in 96-well culture plates and cultured for 24 hours. The cells were then treated with different proteasome inhibitors or other compounds for an additional 24 hours. The cell lysates were extracted, and luciferase activities were measured by a luciferase assay kit (Promega Corp., Madison, Wisconsin, USA) and normalized to protein contents.

Northern blot analysis. FRC cells were treated with different concentrations of PS1 for 6 hours, and total RNA was extracted from FRC cells using RNAzol B method (Tel-Test Inc., Friendswood, Texas, USA). To examine the effects of PS1 on mRNA expression in vivo, PS1 was also injected subcutaneously over the surface of calvariae of 1-month-old ICR Swiss mice, mice were sacrificed 24 hours later, and total RNA was extracted. Enrichment of polyadenylated RNA was obtained using oligo-dT cellulose columns (Stratagene, La Jolla, California, USA). Five micrograms of poly $\left(\mathrm{A}^{+}\right) \mathrm{RNA}$ was denatured in $2.2 \mathrm{M}$ formaldehyde and $50 \%$ formamide and run on a $1 \%$ agarose gel containing $2.2 \mathrm{M}$ formaldehyde. The gels were transferred to a Nytran filter (Schleicher \& Schuell Inc., Keene, New Hampshire, USA) by capillary blotting with $20 \times$ 
SSC $(1 \times \mathrm{SSC}=150 \mathrm{mM} \mathrm{NaCl}, 15 \mathrm{mM} \mathrm{Na}$ citrate, $\mathrm{pH}$ 7.0). The RNA was then cross-linked to the filter by UV irradiation (Stratalink; Stratagene). Prehybridization was carried out at $56^{\circ} \mathrm{C}$ in $5 \times \mathrm{SSC}$ containing $50 \%$ formamide and $150 \mu \mathrm{g} / \mathrm{ml}$ of denatured salmon sperm DNA. After 1-2 hours of prehybridization, the DNA probes were added to the hybridization solution at a concentration of $5 \times 10^{5} \mathrm{cpm} / \mathrm{ml}$. Hybridization was carried out for 15 hours at $56^{\circ} \mathrm{C}$. The filters were then washed twice with $2 \times$ SSC and $0.1 \%$ SDS, once with $0.5 \%$ SSC and $0.1 \%$ SDS, and once with $0.1 \times$ SSC and $0.1 \% \mathrm{SDS}$ at $56^{\circ} \mathrm{C}$ for 15 minutes each. The filters were dried at room temperature, exposed at $-70^{\circ} \mathrm{C}$ overnight, and then quantitated in counts per minute using an AMBIS Image Acquisition and Analysis System (AMBIS Inc., San Diego, California, USA).

BMP-2 ELISA. Hu09 cells were initially cultured with $\alpha$-MEM supplemented with $10 \%$ FCS for 24 hours. The cells were then treated with different proteasome inhibitors for 24 hours. After this incubation, the conditioned media was transferred into microcentrifuge tubes and centrifuged at $21,000 \mathrm{~g}$ for 2-3 minutes to remove cellular debris. The concentration of BMP- 2 in the supernatant was then determined using a Quantikine BMP-2 ELISA (R\&D Systems Inc.). Recombinant human BMP-2 (hBMP-2; R\&D Systems Inc.) was used as a standard.

Proteasome activity assay. This technique was used to assess the effects of inhibition of proteasome activity using a fluorogenic peptide chymotryptic substrate as described (14). The $20 \mathrm{~S}$ proteasomes from the methanoarchaeon Methanosarcina thermophila produced in Escherichia coli and the substrate Suc-Leu-LeuVal-Tyr-AMC were obtained from Calbiochem-Novabiochem Corp. Briefly, serial dilutions of the inhibitor to be tested were mixed with proteasome solution at a proteasome concentration of 0.01 $\mathrm{mg} / \mathrm{ml}$. After 30 minutes of incubation at $37^{\circ} \mathrm{C}$, substrate solution at a final concentration of $25-30 \mu \mathrm{g} / \mathrm{ml}$ was added; the mixture was incubated at $37^{\circ} \mathrm{C}$ and then read at 15,30, and 60 minutes in a Titertek Fluoroskan II (MTX Lab Systems Inc., Vienna, Virginia, USA). The percentage of diminution in fluorescence in the presence compared with the absence of inhibitor was determined for each and the $\mathrm{EC}_{50}$ were calculated. DNA constructs. Human full-length Gli3 (FL-Gli3) expression plasmid was kindly provided by Shunsuke Ishii (15). The N-terminal fragment form of Gli3 (trGli3) cDNA encoding amino acid 1-748 was derived from the FL-Gli3 cDNA. The pact-Flag-Gli3 was digested with $\mathrm{ClaI} / \mathrm{XbaI}$ and a polylinker containing the ClaI site, the GAAACCCCATAG sequence, and the $\mathrm{XbaI}$ site was then cloned into the $\mathrm{ClaI} / \mathrm{XbaI}$ sites of the pact-Flag-Gli3 plasmid.

Murine $\beta$-TrCP cDNA was amplified by RT-PCR using template RNA extracted from $2 \mathrm{~T} 3$ osteoblast precursor cells and then cloned into p3xFlag-CMV vector (Sigma-Aldrich). The nucleotide sequence was verified by sequencing the entire cDNA.
Luciferase assay. To define the response region in the BMP-2 promoter for proteasome inhibitors, a series of deletion constructs of the BMP-2 promoter were generated and cloned into a pGL3 vector. These constructs were transfected with $\beta$-galactosidase ( $\beta$-gal) with or without trGli3 expression plasmid in C2C12 cells using Lipofectamine Plus reagents (Life Technologies Inc., Rockville, Maryland, USA). Twenty-four hours after transfection, cells were lysed with lysis buffer, and luciferase activities were measured using a luciferase assay kit (Promega Corp.). The luciferase activities were normalized by the $\beta$-gal activities. Sitespecific mutations were created in the intact promoter by using PCR-directed mutagenesis (Stratagene) on a construct $-310 /+165$ BMP- 2 promoter. The designed mutations were verified by sequencing.

Western blot analysis. The 293 and C3H10T1/2 cells were plated in six-well culture plates and cultured for 24 hours. Flag-Gli3 expression plasmid was transfected into these cells. Twenty-four hours after transfection, the cells were treated with 3-isobutyl-1-methylxanthine (IBMX;200 $\mu \mathrm{M}$ ) and different concentrations of proteasome inhibitors and then cultured for additional 24 hours. The cell lysates were then extracted, mixed with sample buffer, and run on SDS-PAGE gels (Mini-Protein II ready gels; Bio-Rad Laboratories Inc., Hercules, California, USA). The proteins were transblotted on a PVDF membrane (Bio-Rad Laboratories Inc.) in transblotting buffer ( $25 \mathrm{mM}$ Tris, $192 \mathrm{mM}$ glycine, and $20 \%$ [vol $/ \mathrm{vol}]$ methanol, $\mathrm{pH} 8.3$ ) at $4{ }^{\circ} \mathrm{C}$ for 1 hour. The membrane was blocked with $5 \%$ milk in TBS-T (TBS plus $1 \%$ Tween 20) for 1 hour at room temperature and incubated with anti-Flag M2 mAb (2 $\mu \mathrm{g} / \mathrm{ml}, 1: 2,000$ dilution) in 5\% milk in TBS-T for 1 hour at room temperature. The incubation with HRP-conjugated anti-mouse IgG Ab (1:5,000; Amersham International, Amersham, United Kingdom) was performed at room temperature for 1 hour. The membrane was then washed six times with TBS-T buffer for 5 minutes. Immunostaining was detected using an enhanced chemiluminescence system (Amersham International).

\section{Results}

Proteasome inbibitors stimulate bone formation in bone organ cultures. During an examination of the role of the transcription factor NF- $\mathrm{\kappa B}$ in osteoblast differentiation, we assessed the effects of compounds that inhibit NF-KB stimulation of bone formation in cultures of neonatal murine calvarial bones. These experiments were performed as described previously (10). We found that some but not all of these compounds caused an obvious increase in osteoblast numbers and in new bone area in calvarial bone organ cultures compared with calvarial bones incubated with control media (Figure 1, a-e; Table 1). The only compounds that increased bone formation in vitro, however, were compounds that also inhibited proteasomal activity. We found that compounds that inhibit proteasomal activity, such as the natural products lactacystin, 


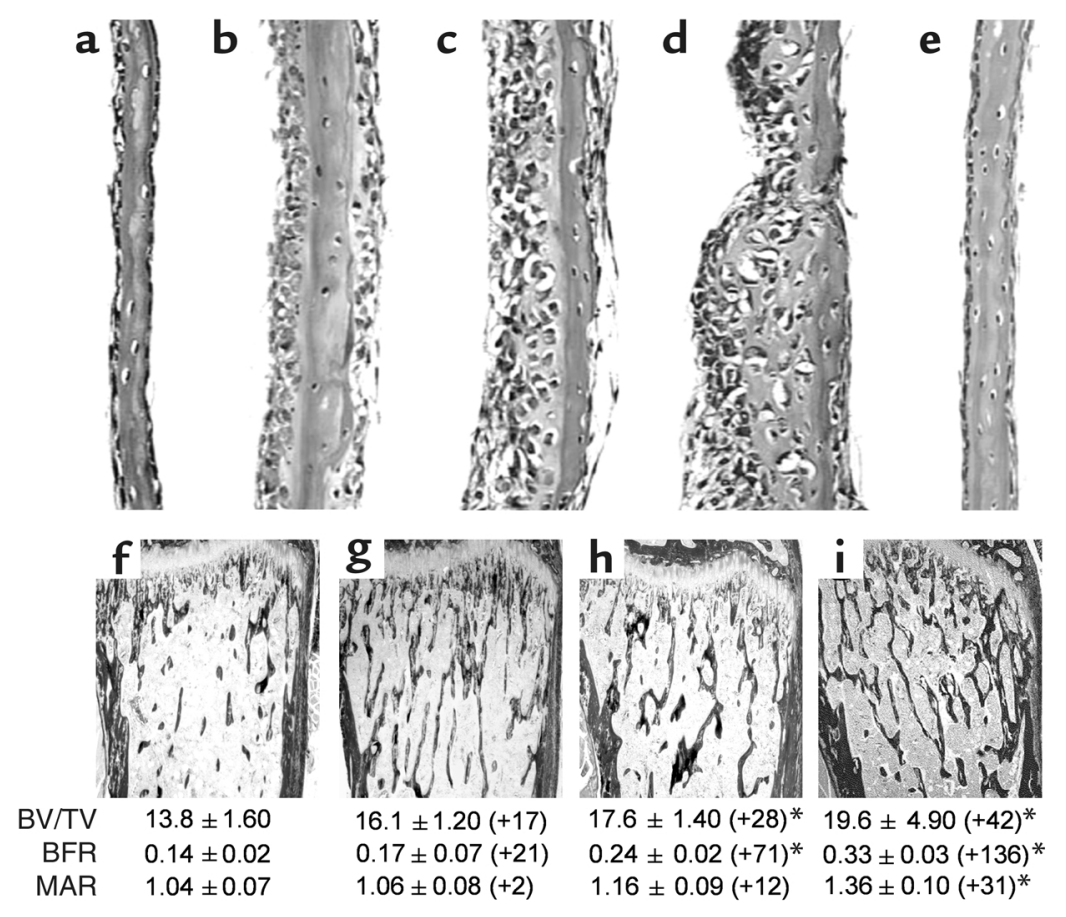

\begin{abstract}
Figure 1
Proteasome inhibitors stimulate bone formation in vitro and in vivo. (a-e) Histologic sections of cultured murine neonatal calvarial bones treated with either (a) media alone, (b) lactacystin $(2.5$ $\mu \mathrm{M}),(\mathbf{c})$ PS1 $(0.1 \mu \mathrm{M}),(\mathbf{d})$ epoxomicin $(0.01$ $\mu \mathrm{M})$, or $(\mathbf{e})$ eponemycin $(0.5 \mu \mathrm{M})$. (f-i) Histologic sections, BFR, and MAR of murine proximal tibia from mice treated daily for 5 days and sacrificed 16 days later. (f) Vehicle, (g) PTH (0.08 $\mathrm{mg} / \mathrm{kg} /$ day subcutaneously), (h) PS1 (2 $\mathrm{mg} / \mathrm{kg} /$ day subcutaneously), (i) epoxomicin (0.1 $\mathrm{mg} / \mathrm{kg} /$ day intraperitoneally). Values in parentheses are percentage of change from vehicletreated controls. BV/TV bone volume/tissue volume. ${ }^{*} P<0.05$.
\end{abstract}

epoxomicin, and PS1, stimulated bone formation in vitro (Figure 1, a-e; Table 1). These compounds are different, since PS1 is a peptide aldehyde (Z-lle-Glu$(\mathrm{OTBu})$-Ala-Leu-H), epoxomicin is an epoxyketone, and lactacystin is a natural product in which the active form is a $\beta$-lactone derivative. Epoxomicin reacts primarily with the chymotrypsin-like site, whereas the related and less-potent epoxyketone eponemycin reacts with the caspaselike and chymotrypsin-like sites at similar rates (16). We found that eponemycin was ineffective in increasing bone formation at concentrations similar to those where epoxomicin caused marked effects (Figure 1e; Table 1 ). The effects of proteasome inhibitors on bone formation were dose dependent and occurred in response to concentrations of epoxomicin as low as $10 \mathrm{nM}$, which is a far more potent effect than that observed in response to any other small molecule in stimulating bone formation. The hydroxymethyl glutaryl-CoA reductase inhibitor, simvastatin, which also stimulates bone formation in this assay, is not effective in doses of less than $100 \mathrm{nM}$ (Table 1) (11). We also

\footnotetext{
Figure 2

Proteasome inhibitors stimulate bone formation in murine calvariae. (a-e) Histological sections of calvariae from mice injected over the right side of the calvarium three times a day for 5 days with either ( $\mathbf{a}$ and $\mathbf{e}$ ) vehicle control, (b) PS1 at $0.1 \mathrm{mg} / \mathrm{kg} /$ day, (c) PS1 at $1 \mathrm{mg} / \mathrm{kg} /$ day, (d) PS1 at $5 \mathrm{mg} / \mathrm{kg} /$ day, (f) epoxomicin at $0.05 \mathrm{mg} / \mathrm{kg} /$ day, $(\mathbf{g})$ epoxomicin at $0.1 \mathrm{mg} / \mathrm{kg} / \mathrm{day}$, and (h) epoxomicin at 0.5 $\mathrm{mg} / \mathrm{kg} /$ day. Arrows indicate width of new bone.
}

examined a series of related compounds for their ability to increase bone formation using calvarial cultures. These included other proteasome inhibitors, such as YU101 (ac-hFLFL-epoxide) (9), MG262, MG132, MG115, which we found to be active. Inhibitors of nonproteasomal proteases, such as TLCK, TPCK, ALLM, EST, and other inhibitors of the ubiquitous transcription factor NF- $\kappa \mathrm{B}$, namely PDTC, PPM-18, and Bay 11-7082, had no effect. Proteasome inhibitors inhibit NF- $\mathrm{KB}$ because translocation of NF- $\kappa B$ to the nucleus is dependent on the degradation of $\mathrm{I}-\mathrm{\kappa B}$, a process controlled by the proteasome (17). The only compounds that stimulated bone formation were those compounds that also inhibited proteasome activity. a

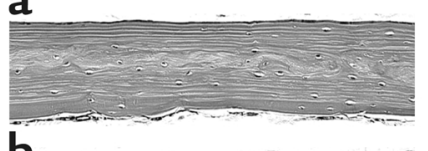

b

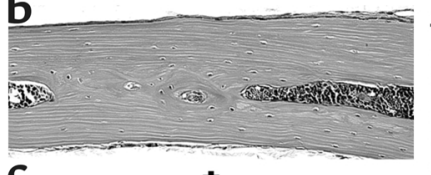

C
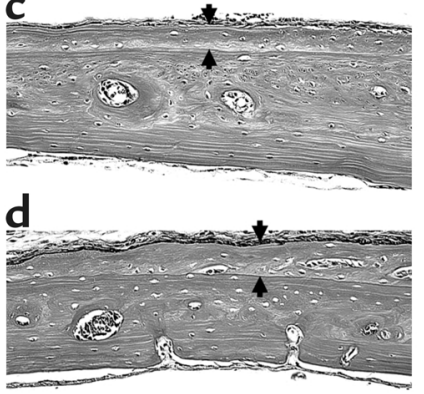

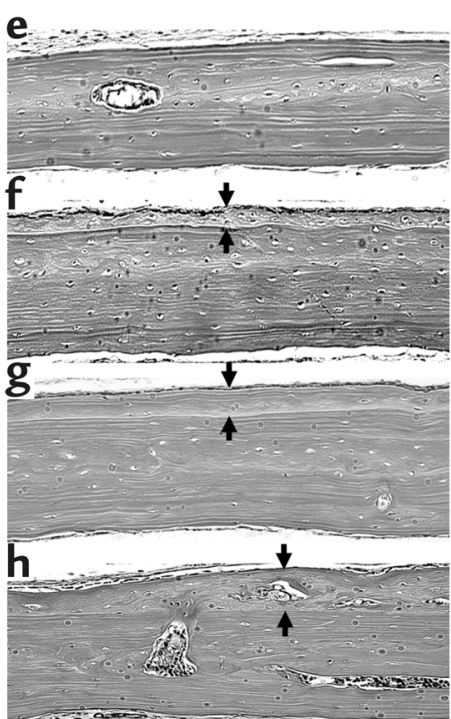




\section{Table 1}

Effects of different proteasome inhibitors and the statin simvastatin at multiple concentrations on bone formation in explants of neonatal murine calvarial bones cultures

\begin{tabular}{|c|c|c|c|}
\hline Treatment & $\begin{array}{l}\text { Concentration } \\
\qquad(\mu \mathrm{M})\end{array}$ & $\begin{array}{c}\text { New bone area } \\
\left(\mathrm{mm}^{2} \times 10^{-3}\right)\end{array}$ & $\begin{array}{c}\text { Cell number } \\
\text { (per } 0.3 \mathrm{~mm} \text { bone) }\end{array}$ \\
\hline Control media & Vehicle alone & $3.1 \pm 0.2$ & $104 \pm 5$ \\
\hline BMP-2 (40 ng/m & & $5.6 \pm 0.4^{A}$ & $154 \pm 5^{A}$ \\
\hline Lactacystin & $\begin{array}{c}\text { Vehicle alone } \\
0.62 \\
1.25 \\
2.5 \\
5\end{array}$ & $\begin{array}{l}3.4 \pm 0.4 \\
3.2 \pm 0.5 \\
4.7 \pm 0.7 \\
5.9 \pm 0.9 \AA \\
5.4 \pm 0.6\end{array}$ & $\begin{array}{l}104 \pm 5 \\
105 \pm 6 \\
114 \pm 7 \\
160 \pm 6^{A} \\
157 \pm 6^{A}\end{array}$ \\
\hline PS1 & $\begin{array}{c}\text { Vehicle alone } \\
0.006 \\
0.0125 \\
0.025 \\
0.05 \\
0.1\end{array}$ & $\begin{array}{l}2.9 \pm 0.3 \\
4.3 \pm 0.1 \\
5.5 \pm 0.3^{\mathrm{A}} \\
6.0 \pm 0.9^{\mathrm{A}} \\
8.0 \pm 0.6^{\mathrm{A}} \\
8.2 \pm 1.2^{\mathrm{A}}\end{array}$ & $\begin{array}{l}109 \pm 7 \\
116 \pm 4 \\
120 \pm 6 \\
132 \pm 10^{A} \\
162 \pm 15^{A} \\
179 \pm 15^{A}\end{array}$ \\
\hline Epoxomicin & $\begin{array}{c}\text { Vehicle alone } \\
0.00062 \\
0.00125 \\
0.0025 \\
0.005 \\
0.01\end{array}$ & $\begin{array}{l}2.8 \pm 0.4 \\
2.8 \pm 0.3 \\
2.8 \pm 0.4 \\
4.0 \pm 0.4 \\
6.5 \pm 0.8^{\mathrm{A}} \\
6.8 \pm 0.5^{\mathrm{A}}\end{array}$ & $\begin{array}{l}105 \pm 6 \\
106 \pm 8 \\
101 \pm 7 \\
119 \pm 5 \\
162 \pm 6^{A} \\
173 \pm 6^{A}\end{array}$ \\
\hline Eponemycin & $\begin{array}{c}\text { Vehicle alone } \\
0.031 \\
0.062 \\
0.125 \\
0.25 \\
0.5\end{array}$ & $\begin{array}{l}3.2 \pm 0.6 \\
3.1 \pm 0.5 \\
2.9 \pm 0.3 \\
3.2 \pm 0.4 \\
3.4 \pm 0.4 \\
3.5 \pm 0.8\end{array}$ & $\begin{array}{r}103 \pm 6 \\
98 \pm 6 \\
102 \pm 8 \\
105 \pm 7 \\
96 \pm 5 \\
114 \pm 6\end{array}$ \\
\hline $\begin{array}{l}\text { Simvastatin } \\
\text { (Experiment 1) }\end{array}$ & $\begin{array}{c}\text { Vehicle alone } \\
0.062 \\
0.125 \\
0.25 \\
0.5\end{array}$ & $\begin{array}{r}3.4 \pm 0.8 \\
5.3 \pm 1.1 \\
8.2 \pm 0.7^{\mathrm{A}} \\
14.5 \pm 1.8^{\mathrm{A}} \\
14.0 \pm 1.1^{\mathrm{A}}\end{array}$ & $\begin{array}{c}98 \pm 7 \\
110 \pm 9 \\
135 \pm 4^{A} \\
167 \pm 17^{A} \\
190 \pm 26^{A}\end{array}$ \\
\hline $\begin{array}{l}\text { Simvastatin } \\
\text { (Experiment 2) }\end{array}$ & $\begin{array}{c}\text { Vehicle alone } \\
0.062 \\
0.125 \\
0.25 \\
0.5\end{array}$ & $\begin{array}{l}2.9 \pm 0.3 \\
3.1 \pm 0.3 \\
5.2 \pm 0.7^{\mathrm{A}} \\
7.1 \pm 0.8^{\mathrm{A}} \\
7.4 \pm 1.5^{\mathrm{A}}\end{array}$ & $\begin{array}{c}103 \pm 5 \\
97 \pm 5 \\
121 \pm 3^{A} \\
143 \pm 6^{A} \\
165 \pm 10^{A}\end{array}$ \\
\hline
\end{tabular}

Data is expressed as means \pm SEM. ${ }^{A} P<0.05$ versus vehicle alone.

Effects of proteasome inhibitors on bone formation in vivo. We next administered PS1 subcutaneously and epoxomicin intraperitoneally to normal intact Swiss white mice for 5 days (Figure 1, $\mathrm{f}-\mathrm{i}$ ). We used PTH as a control because, when used over longer periods, it has powerful anabolic effects on bone formation (18). PTH did not have significant effects with only 5 days of daily subcutaneous administration, however (Figure 1g). PS1 caused an increase in trabecular bone volume of $28 \%$ accompanied by a $71 \%$ increase in BFRs measured by dynamic parameters compared with vehicle-treated mice (Figure 1h). This increase in BFR was present when the animals were sacrificed, which was over 2 weeks after the compound was last administered. This increased BFR shows the increase in trabecular bone volume was due to an absolute increase in the rate of bone formation rather than a secondary effect due to a decreased bone resorption. Although there was a minor decrease in osteoclast numbers, suggesting that bone resorption may also have been reduced slightly, there were no effects of these compounds on rates of bone resorption in organ cultures (data not shown), and the measured increases in rates of bone formation are so pronounced that the increases in bone volume cannot be ascribed to a simple reduction in bone turnover. Epoxomicin (Figure 1i) caused similar responses to those of PS1, but at doses at least 20-fold less. Subsequent experiments where epoxomicin was injected into mice at doses between 0.1 and $0.004 \mathrm{mg} / \mathrm{kg} /$ day for 5 days show that it caused a significant dose-responsive increase in bone formation (Table 2). These increases in BFR and bone volume after only 5 days of treatment are of a degree comparable to those that require over 1 month of treatment with other anabolic agents such as the statins and PTH (11).

Dose-response effects of PS1 $(0.1-5 \mathrm{mg} / \mathrm{kg} /$ day, daily subcutaneous injection for 5 days) on bone formation were also examined in calvariae following local subcutaneous injection. PS1 stimulated new bone formation in a dose-dependent manner and did not cause toxic effects in this dose range (Figure 2; Table 3).

Relationship of the stimulation of bone formation to inbibition of proteasome activity. One of the authors (C.M. Crews) has optimized a series of peptide $\alpha^{\prime}, \beta^{\prime}$-epoxyketones related to epoxomicin as molecular probes to inhibit the catalytic activities of the proteasome more selectively (9). We also tested a number of these compounds for their capacity to stimulate bone formation in calvarial organ cultures (Figure 3). There was no effect of a peptide epoxyketone that preferentially inhibits the postacidic or caspaselike site on bone formation in vitro (data not shown), but in contrast the most potent and selective inhibitor of the chymotrypsin-like site, an amino-terminally acetylated epoxyketone peptide, Ac-hFLFL-epoxide (9), stimulated bone formation at concentrations of $10 \mathrm{nM}$ (Figure 3 ). We found there was a strong positive correlation $(r=0.94)$ between the capacity of each of these compounds to inhibit proteasomal activity and their boneforming activity (Figure 3).

Proteasome inbibitors stimulate BMP-2 expression. Since the ubiquitin-proteasome pathway regulates the proteolytic processing of Cubitus interruptus (Ci) (19), which regulates expression of decapentaplegic $(d p p)$ gene $(20,21)$, the Drosophila homologue of the BMP-2/BMP-4 genes, we speculated that these compounds may be increasing

\section{Table 2}

The dose-response effects on trabecular tibial bone volume of PS1 injected subcutaneously and epoxomicin injected intraperitoneally in normal intact Swiss white mice

\begin{tabular}{lccc}
\hline Treatment & Dose $(\mathrm{mg} / \mathrm{kg} /$ day $)$ & $\% \mathrm{BV} / \mathrm{TV}$ & $\%$ Increase \\
PS1 & Vehicle alone & $13.1 \pm 2.2$ & \\
& 1 & $22.3 \pm 2.4^{\mathrm{A}}$ & 36 \\
Epoxomicin & 2 & $17.6 \pm 1.2^{\mathrm{A}}$ & 25 \\
& Vehicle alone & $11.7 \pm 3.4$ & \\
& 0.004 & $14.3 \pm 1.8$ & 22 \\
& 0.02 & $18.5 \pm 1.0^{\mathrm{A}}$ & 58 \\
& 0.1 & $23.2 \pm 4.2^{\mathrm{A}}$ & 98 \\
\hline
\end{tabular}

Data are expressed as means \pm SEM. ${ }^{A} P<0.05$ versus vehicle alone. $B V / T V$, bone volume/tissue volume. 


\section{Table 3}

The dose-response effects on calvarial periosteal bone formation of PS1 and epoxomicin injected subcutaneously over the calvariae of Swiss white mice

\begin{tabular}{lccc}
\hline Treatment & $\begin{array}{c}\text { Dose } \\
(\mathrm{mg} / \mathrm{kg} / \text { day })\end{array}$ & $\begin{array}{c}\text { Total bone area } \\
\left(\mu \mathrm{m}^{2}\right)\end{array}$ & $\%$ Increase \\
PS1 & Vehicle alone & $0.64 \pm 0.03$ & \\
& 0.1 & $0.74 \pm 0.02^{\mathrm{A}}$ & 22 \\
& 1 & $0.83 \pm 0.02^{\mathrm{A}}$ & 35 \\
Epoxomicin & 5 & $0.79 \pm 0.03^{\mathrm{A}}$ & 32 \\
& Vehicle alone & $0.68 \pm 0.02$ & \\
& 0.05 & $0.78 \pm 0.03^{\mathrm{A}}$ & 15 \\
& 0.1 & $0.87 \pm 0.02^{\mathrm{A}}$ & 28 \\
& 0.5 & $0.91 \pm 0.03^{\mathrm{A}}$ & 34
\end{tabular}

Data are expressed as means \pm SEM. ${ }^{A} P<0.001$ verses vehicle alone.

BMP-2 and - 4 expression in osteoblasts. Accordingly, we tested the effects of proteasome inhibitors on BMP-2 and BMP-4 expression in osteoblasts and found that these inhibitors of the ubiquitin-proteasome pathway enhance BMP-2 expression using murine 2T3 osteoblasts and human Hu09 and MG-63 osteoblasts. Epoxomicin and PS1 both increased luciferase activity in 2T3 cells stably transfected with the murine BMP-2 promoter $(-2712 /+165)$ operatively linked to the firefly luciferase cDNA (Figure 4a). They were considerably more potent as stimulators of BMP-2 promoter activity than the statins, which have been shown recently to stimulate BMP-2 expression and enhance bone formation in vitro and in vivo (Table 1) (11).

To determine the specificity of proteasome inhibitors on BMP-2 expression, we also examined the effects of the proteasome inhibitors PS1 and epoxomicin on mRNA expression of BMP-2, BMP-4, BMP-6, and the $\mathrm{BMP}$ antagonists noggin, gremlin, and chordin in primary FRC osteoblasts in vitro and in calvarial bone tissues in vivo. We found that PS1 increased BMP-2 mRNA expression, but had no significant effects on mRNA expression of BMP-4 and BMP-6 (Figure 4b). The expression of chordin and gremlin in the cells was so low that it was barely detectable, and whereas noggin mRNA expression was detectable, no significant changes were seen following addition of epoxomicin or PS1 (data not shown). PS1 and epoxomicin also increased BMP-2 mRNA expression in cultured human MG-63 osteoblastic cells but had no effect on BMP-4 or BMP-6 mRNA expression (data not shown).

We next tested a number of proteasome inhibitors for their ability to increase accumulation of BMP-2 protein in conditioned media from human $\mathrm{Hu} 09$ osteoblastic cells (Table 4). Increased expression of BMP-2 protein correlated positively $(r=0.95)$ with their ability to inhibit proteasome activity (Figure 4c). We also found there was a strong positive correlation $(r=0.98)$ between the ability of each of these compounds to stimulate bone formation and to stimulate the expression of BMP-2 protein (Figure $4 \mathrm{~d}$ ). These results are consistent with the notion that the catalytic activity of the proteasome is important in the regu- lation of BMP-2 transcription and protein expression, as well as subsequent bone formation.

Noggin inhibits bone formation induced by proteasome inhibitors. Our data suggest that proteasome inhibitors stimulate bone formation by enhancing BMP-2 expression in osteoblasts. It is also possible, however, that other mechanisms could be involved in their effects to stimulate bone formation. To determine the importance of the BMP pathway in the effects of proteasome inhibitors on bone formation, we treated bone organ cultures with the proteasome inhibitors epoxomicin (20 nM) and with murine noggin (noggin/Fc chimera; $2 \mu \mathrm{g} / \mathrm{ml}$ ), the naturally occurring high-affinity binding protein for BMP-2, BMP-4, and BMP-7 $(22,23)$ (Figure $5)$. We found that noggin completely inhibited the bone-stimulating effects of the proteasome inhibitors epoxomicin (Figure 5, c and d) and PS1 (data not shown), as well as BMP-2 (Figure 5, e and f), in calvarial organ cultures, but had no effect on bone formation stimulated by acidic FGF (Figure 5, g and h).

Noggin also inhibits BMP-4 and BMP-6 in addition to BMP-2 $(22,23)$. As described above (Figure 3b), we found no increase in BMP-4 or BMP- 6 mRNA expression after addition of the proteasome inhibitor PS1. This suggests that BMP-2 rather than BMP-4 or BMP- 6 was responsible for the bone-forming effects of the compounds seen in organ culture that was inhibited by noggin.

Proteasome inhibitors inhibit the proteolytic processing of Gli3 protein. $\mathrm{C} i$ is proteolytically processed to a N-terminal fragment form, and this regulates the $d p p$ gene in Drosophila, acting as a transcriptional repressor for this gene $(20,21)$. The mammalian homologues of $\mathrm{Ci}$ are Gli1, Gli2, and Gli3. In a manner similar to $\mathrm{Ci}$, Gli3 is processed to trGli3 (15) These reports indicate the proteolytic processing of Gli3 protein is regulated by a cAMP-dependent PKA pathway, and an inhibitor of

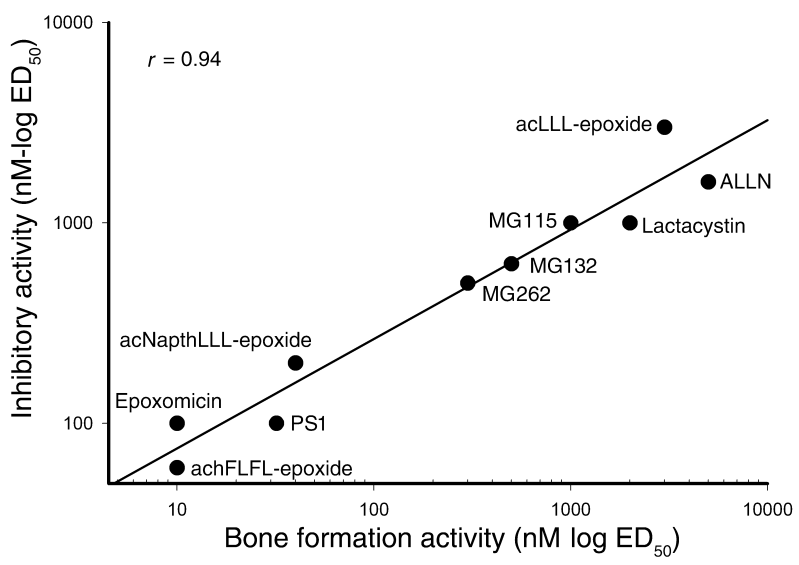

Figure 3

Proteasome inhibition correlates with bone formation. The stimulation of bone formation activity of these different proteasome inhibitors in calvarial bone organ cultures correlates strongly with the ability of these compounds to inhibit the activity of the proteasome. $\mathrm{ED}_{50}$ is the effective dose required to either inhibit $50 \%$ of the proteasomal activity or stimulate $50 \%$ of the bone formation activity. 

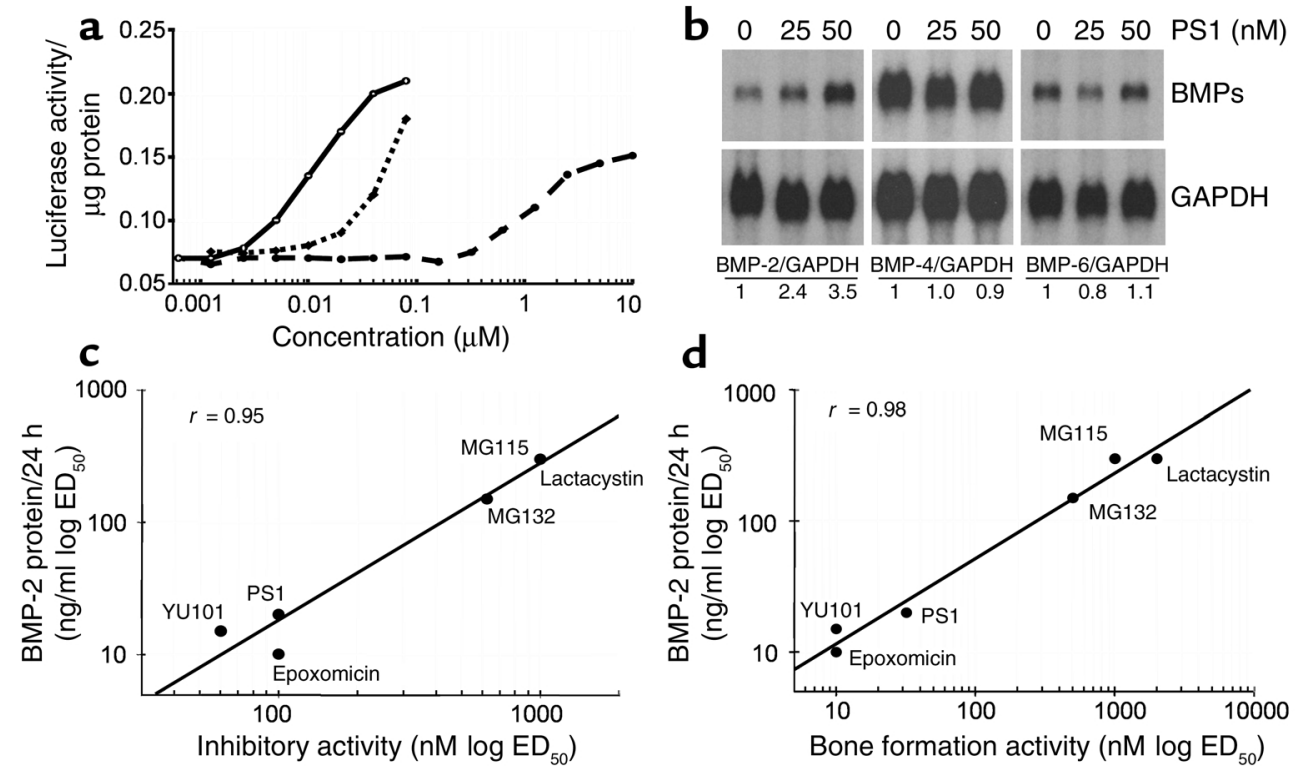

\section{Figure 4}

Effect of proteasome inhibition on BMP-2 protein expression and bone formation. (a) Luciferase activity of cell lysates of 2T3 cells transfected with murine BMP-2 promoter $(-2712 /+165)$ operatively linked to firefly luciferase cDNA and treated with either simvastatin (dashed line), PS1 (dotted line), or epoxomicin (solid line). (b) Effects of PS1 (50 and $100 \mathrm{nM}$ ) on mRNA expression of BMP-2, BMP-4, and BMP-6 in FRC cells. FRC cells were treated with PS1 (50 and $100 \mathrm{nM}$ ) for 6 hours and cultured for 48 hours. The mRNA expression of BMP-2, BMP-4, and BMP- 6 was detected by Northern blot analysis and quantitated by the Phospholmager analysis method. PS1 increased BMP-2 mRNA expression 2.4-fold and 3.5-fold at concentrations of 50 and $100 \mathrm{nM}$, but had no significant effect on BMP-4 and BMP-6 mRNA expression. (c) Correlation of BMP-2 protein production from Hu09 human osteoblastic cells and inhibitory activity on the proteasome among proteasome inhibitors of different types. (d) Correlation of BMP-2 protein production from Hu09 human osteoblastic cells and bone formation activity (as assessed by effects on calvarial bone organ cultures).

phosphodiesterase, IBMX, induces Gli3 degradation (15). To determine the effects of proteasome inhibitors on the processing of Gli3 protein, we transfected a Flagtagged FL-Gli3 expression plasmid into 293 and C3H10T1/2 cells and treated these cells with IBMX in the presence or absence of different concentrations of the proteasome inhibitors PS1 and epoxomicin. IBMX induced Gli3 degradation and production of a truncated form of Gli3 (Gli3 ${ }^{85}$ ) (Figure 6, a and b). Treatment with different concentrations of PS1 or epoxomicin reversed the effects of IBMX on Gli3 degradation and prevented the production of trGli3
$\left(\mathrm{Gli3}^{85}\right.$ ) (Figure 6, a and b). Similar results were also observed in C3H10T1/2 cells (data not shown). These results demonstrate that the proteolytic processing of Gli3 protein is proteasome dependent and that proteasome inhibitors inhibit the conversion of Gli3 precursor protein into trGli3.

Truncated Gli3 is a transcriptional repressor of the BMP-2 gene. We further examined the effects of Gli3 on BMP-2 gene transcription by cotransfecting expression plasmids of a FL-Gli3 and trGli3, along with the BMP-2 promoter $(-2712 /+165-1 u c)$, into osteoblast precursor $\mathrm{C} 2 \mathrm{C} 12$ and $2 \mathrm{~T} 3$ cells and osteoblast progenitor

\section{Figure 5}

Noggin inhibits bone formation induced by proteasome inhibitors. Histologic sections of cultured murine neonatal calvarial bones treated with (a) media alone, (b) noggin (2 $\mu \mathrm{g} / \mathrm{ml})$, (c) epoxomicin (20 nM), (d) epoxomicin (20 nM) and $\operatorname{noggin}(2 \mu \mathrm{g} / \mathrm{ml}),(\mathbf{e}) \mathrm{rhBMP}-2(100 \mathrm{ng} / \mathrm{ml}),(\mathbf{f}) \mathrm{rhBMP}-2$ $(100 \mathrm{ng} / \mathrm{ml})$ and noggin $(2 \mu \mathrm{g} / \mathrm{ml}),(\mathbf{g}) \operatorname{aFGF}(50 \mathrm{ng} / \mathrm{ml}),(\mathbf{h})$ $\operatorname{aFGF}(50 \mathrm{ng} / \mathrm{ml})$ and noggin $(2 \mu \mathrm{g} / \mathrm{ml})$. a

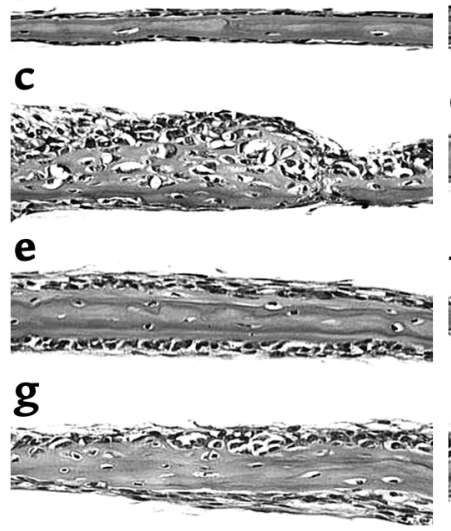

b

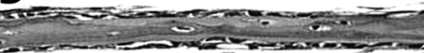

d

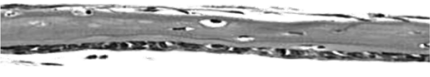

$f$

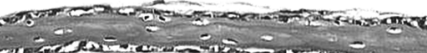

h 
Table 4

Effects of different proteasome inhibitors at multiple concentrations over 24 hours on the production of BMP-2 protein into HU09 cellconditioned medium

\begin{tabular}{|c|c|c|}
\hline Treatment & Concentration $(\mu \mathrm{M})$ & BMP-2 protein $(\mathrm{pg} / \mathrm{ml})$ \\
\hline YU101 & $\begin{array}{c}\text { Vehicle alone } \\
0.0025 \\
0.005 \\
0.010 \\
0.020 \\
0.040\end{array}$ & $\begin{array}{c}37 \pm 5 \\
56 \pm 15 \\
59 \pm 20 \\
119 \pm 22^{A} \\
163 \pm 12^{A} \\
212 \pm 27^{A}\end{array}$ \\
\hline PS1 & $\begin{array}{c}\text { Vehicle alone } \\
0.0062 \\
0.0125 \\
0.025 \\
0.050 \\
0.100\end{array}$ & $\begin{aligned} 67.2 & \pm 5 \\
98 & \pm 12^{\mathrm{A}} \\
139 & \pm 15^{\mathrm{A}} \\
158 & \pm 18^{\mathrm{A}} \\
152 & \pm 22^{\mathrm{A}} \\
156 & \pm 16^{\mathrm{A}}\end{aligned}$ \\
\hline Epoxomicin & $\begin{array}{c}\text { Vehicle alone } \\
0.01 \\
0.02 \\
0.04 \\
0.08\end{array}$ & $\begin{aligned} 36 & \pm 6 \\
50 & \pm 8 \\
108 & \pm 14^{\mathrm{A}} \\
172 & \pm 9^{\mathrm{A}} \\
75 & \pm 11^{\mathrm{A}}\end{aligned}$ \\
\hline MG132 & $\begin{array}{c}\text { Vehicle alone } \\
0.035 \\
0.075 \\
0.100 \\
0.300 \\
0.600\end{array}$ & $\begin{array}{c}71 \pm 13 \\
65 \pm 4 \\
84 \pm 13 \\
107 \pm 11^{\mathrm{A}} \\
140 \pm 14^{\mathrm{A}} \\
145 \pm 6^{\mathrm{A}}\end{array}$ \\
\hline MG115 & $\begin{array}{c}\text { Vehicle alone } \\
0.300 \\
0.600 \\
0.1200\end{array}$ & $\begin{aligned} 71 & \pm 12 \\
71 & \pm 11 \\
149 & \pm 15^{A} \\
74 & \pm 3\end{aligned}$ \\
\hline Lactacystin & $\begin{array}{l}\text { Vehicle alone } \\
125 \\
250 \\
500\end{array}$ & $\begin{aligned} 36 & \pm 6 \\
37 & \pm 8 \\
83 & \pm 12^{\mathrm{A}} \\
117 & \pm 15^{\mathrm{A}}\end{aligned}$ \\
\hline
\end{tabular}

Data are expressed as means \pm SEM. ${ }^{A} P<0.05$ versus vehicle alone.

C3H10T1/2 cells. We found that transfection of FL-Gli3 increased BMP-2 promoter activity (Figure 7a), while transfection of trGli3 markedly inhibited BMP-2 promoter activity in a dose-dependent manner up to $70-80 \%$ (Figure $7 \mathrm{~b}$ ). These results demonstrate trGli3 is a potent repressor of BMP-2 gene transcription.

Truncated Gli3 regulates BMP-2 gene transcription through specific response elements. To define the response region for trGli3 in the BMP-2 promoter, a series of deletion constructs of the BMP-2 promoter (Figure 7c) were cotransfected with a trGli3 expression plasmid. Expression of trGli3 significantly inhibited promoter activity of the BMP-2 deletion constructs, $-2712 /+165,-1803 /+165,-838 /+165$, and $-310 /+165$, but not the construct $-150 /+165$ (Figure $7 d$ ), suggesting the response region for trGli3 is located at $-310 /-150$ region of the BMP- 2 promoter. By sequence analysis, three putative Gli-binding sites were identified in this region (Figure 7c). Mutations of each of these three response elements significantly reduced the activity of trGli3 on the BMP-2 promoter $(-310 /+165)$ (Figure 7e), suggesting all these responsive elements are required for mediating the repressive activity of trGli3 on BMP-2 gene transcription. These results indicate that trGli3 regulates BMP-2 promoter activity through interactions with specific responsive elements in BMP-2 promoter.

Stimulation of BMP-2 gene transcription and bone formation by proteasome inhibitors are Gli3 dependent. To determine if inhibition of the proteolytic processing of Gli3 is required for proteasome inhibitors to stimulate BMP-2 gene transcription, we transfected the trGli3 expression plasmid with the BMP-2 promoter $(-2712 /+165-\mathrm{Luc})$ into C2C12 and 2T3 cells in the presence or absence of different concentrations of the proteasome inhibitors PS1 and epoxomicin. We found that overexpression of trGli3 reduced basal levels of the BMP-2 promoter activity and completely blocked PS1- and epoxomicin-induced BMP-2 gene transcription in C2C212 (Figure 8, a and b) and 2T3 (Figure 8, $\mathrm{c}$ and $\mathrm{d}$ ) cells. These results suggest proteasome inhibitors stimulate BMP-2 gene transcription in a Gli3-dependent manner.

Since Gli3 has been shown to play an important role in bone formation (24), we further determined the effect of the trGli3 on bone formation in calvarial organ culture. The expression plasmid of the trGli3 was transfected into calvarial tissues, and expression of trGli3 significantly inhibited epoxomicin-induced new bone formation in calvariae (Figure 9a). In contrast, expression of trGli3 had no significant effects on insulin-induced bone formation in this same assay (Figure 9b). The new bone formation was quantitated by histomorphometry and presented in Figure 9c. Alkaline phosphatase (ALP) activities in media were also measured. Epoxomicin and insulin significantly increased ALP activity. Expression of the trGli3 blocked epoxomicin but not insulin-induced ALP activity (Figure 9d). These results suggest that proteasome inhibitor-induced new bone formation in organ culture is also Gli3 dependent.

\section{Discussion}

Here we show that inhibition of the ubiquitin-proteasome pathway by proteasome inhibitors promotes BMP-2 expression and osteoblast differentiation in vitro and bone formation in vitro and in vivo. The mechanism by which proteasome inhibitors regulate
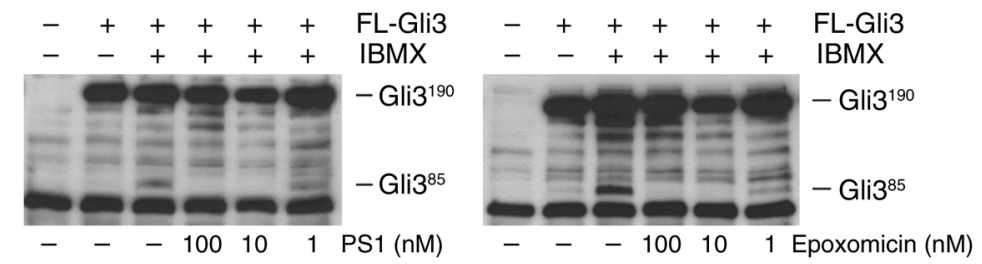

Figure 6

Proteasome inhibitors inhibit the proteolytic processing of Gli3 protein. The 293 cells were transfected with expression plasmid of Flag-tagged FL-Gli3 and treated with 200 $\mu \mathrm{M}$ IBMX in the presence or absence of different concentrations of PS1 (a) and epoxomicin (b) (1, 10, and $100 \mathrm{nM})$. IBMX induced Gli3 degradation and production of trGli3. PS1 reversed IBMX-induced Gli3 degradation in a dose-dependent manner. 

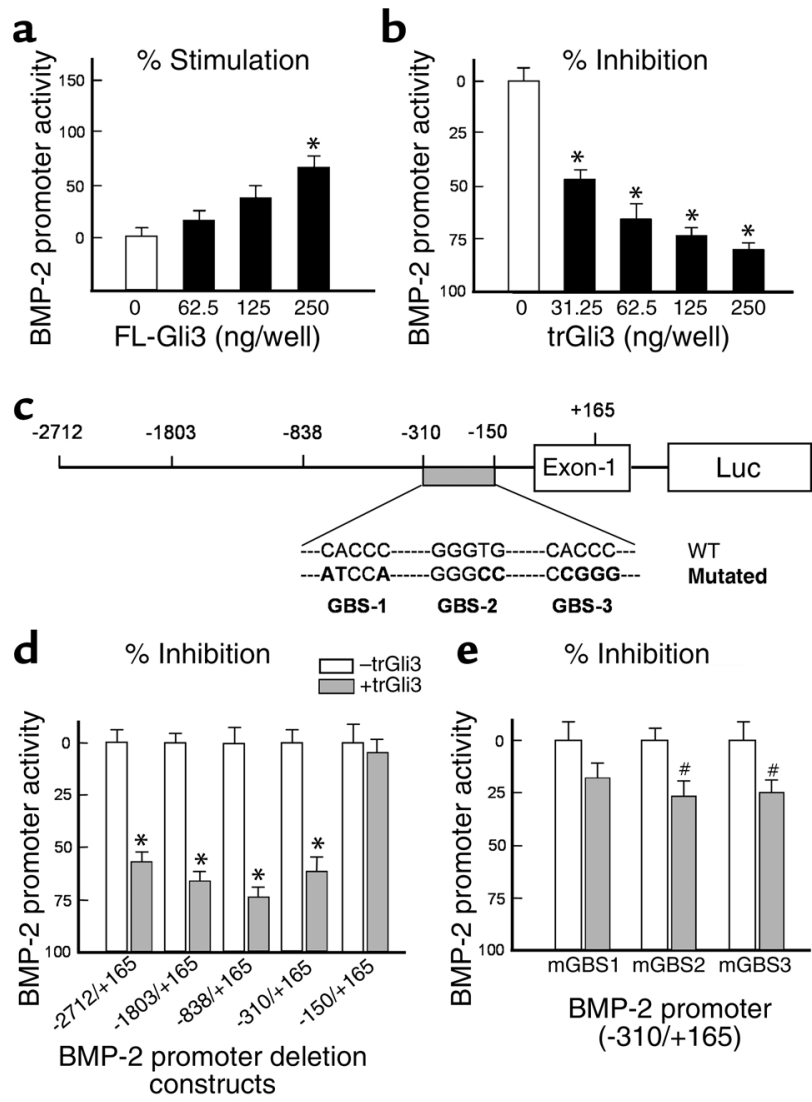

e $\%$ Inhibition

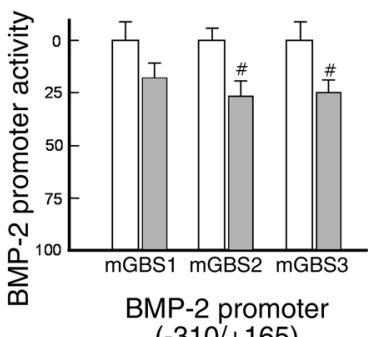

$(-310 /+165)$
BMP-2 gene expression is, at least in part, through inhibiting the proteolytic processing of Gli3 protein. The effects of proteasome inhibitors are dramatic and occur in vitro at doses in the low nanomolar range. We propose that increased expression of BMP-2, which then acts on osteoblasts in an autocrine manner, is responsible, at least in part, for the effects of these compounds on bone formation.

Bone formation is a complex multistep process, which in the adult mammal usually occurs at sites of prior bone resorption. The process is prolonged and comprises a number of distinct phases, including chemotaxis of osteoblast precursors to sites of resorption defects, proliferation of osteoblast precursors, osteoblast differentiation, and ultimately mineralization of the extracellular matrix secreted by osteoblasts. The regula-

\section{Figure 8}

The stimulatory effects of proteasome inhibitors on BMP-2 expression are dependent on Gli3 processing. C2C12 and $2 \mathrm{~T} 3$ cells were transfected with trGli3 (200 ng/well, 24-well plates) and treated with different concentrations of PS1 ( $\mathbf{a}$ and $\mathbf{c}$ ) and epoxomicin (b and $\mathbf{d}$ ) (0-80 nM). Overexpression of trGli3 reduced basal level of BMP-2 promoter activity and completely blocked PS1- and epoxomicininduced BMP- 2 promoter activity $(n=3)$ in $\mathrm{C} 2 \mathrm{C} 12$ (a and $\mathbf{b})$ and $2 \mathrm{~T} 3$ (c and d) cells. ${ }^{*} P<0.05$, compared with nontreatment control; ${ }^{\#} P<0.05$, compared with empty vector-transfected control; two-way ANOVA followed by the Dunnett test.

\section{Figure 7}

Truncated Gli3 inhibits BMP-2 gene transcription through specific response elements. ( $\mathbf{a}$ and $\mathbf{b}$ ) Different amounts of expression plasmids of an FL-Gli3 and trGli3 $(62.5,125$, and $250 \mathrm{ng} / \mathrm{ml})$ were cotransfected with the BMP-2 promoter $(-2712 /+165-$ Luc $)$ in C2C12 cells (24-well culture plates). FL-Gli3 slightly enhanced BMP-2 promoter activity (a), while trGli3 inhibited BMP-2 promoter activity in a dose-dependent manner $(\mathbf{b})(n=4) .{ }^{*} P<0.05$, ANOVA, followed by the Dunnett test. (c) A diagram showing deletion constructs of the BMP-2 promoter, the putative Gli-binding sites in $-310 /-150$ region of BMP-2 promoter, and mutations created in these putative Gli-binding sites (GBS). (d) Expression plasmid of trGli3 was cotransfected with deletion constructs of BMP-2 promoter. trGli3 significantly inhibited promoter activity in constructs $-2712 /+165,-1803 /+165$, $-839 /+165$, and $-310 /+165$, but not the construct $-150 /+165$ $(n=3) .{ }^{*} P<0.05$, unpaired $t$ test. (e) Expression plasmid of trGli3 was cotransfected with BMP-2 promoter $(-310 /+165-$ Luc $)$ constructs with mutations in three putative Gli-binding sites. The inhibitory effect of trGli3 on BMP-2 promoter activity was reversed when these Glibinding sites were mutated. $n=5$; ${ }^{\#} P<0.05$, unpaired $t$ test.

tory factors, which control the process, are generated locally and include the bone growth factors that are incorporated into the bone matrix (1) and released in active form when bone is resorbed (3). Prominent among these are the BMPs, which play a different role from the other bone-growth regulatory factors, since they act predominantly on osteoblasts in an autocrine manner to promote further differentiation (25).

Our observations suggest that proteasome inhibitors enhance bone formation in vivo by stimulation of BMP-2 expression in osteoblasts. The proteasome inhibitors specifically enhanced BMP-2 promoter activity and expression of BMP-2 mRNA. Proteasome inhibitors had no effect on the expression of BMP-4 and BMP- 6 mRNA. The experiments with the noggin
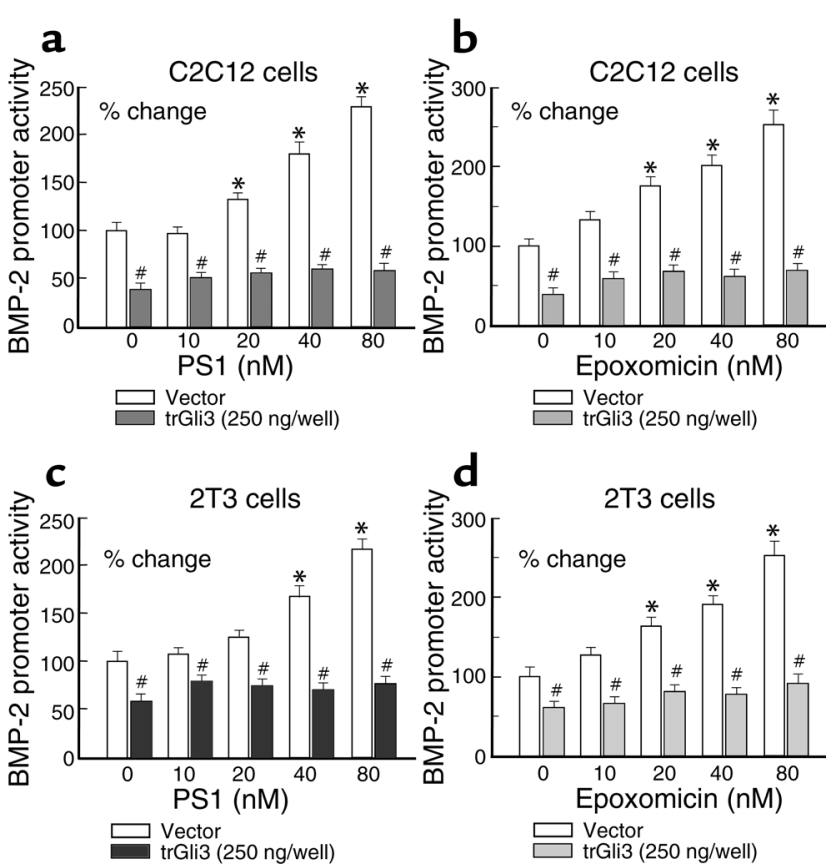

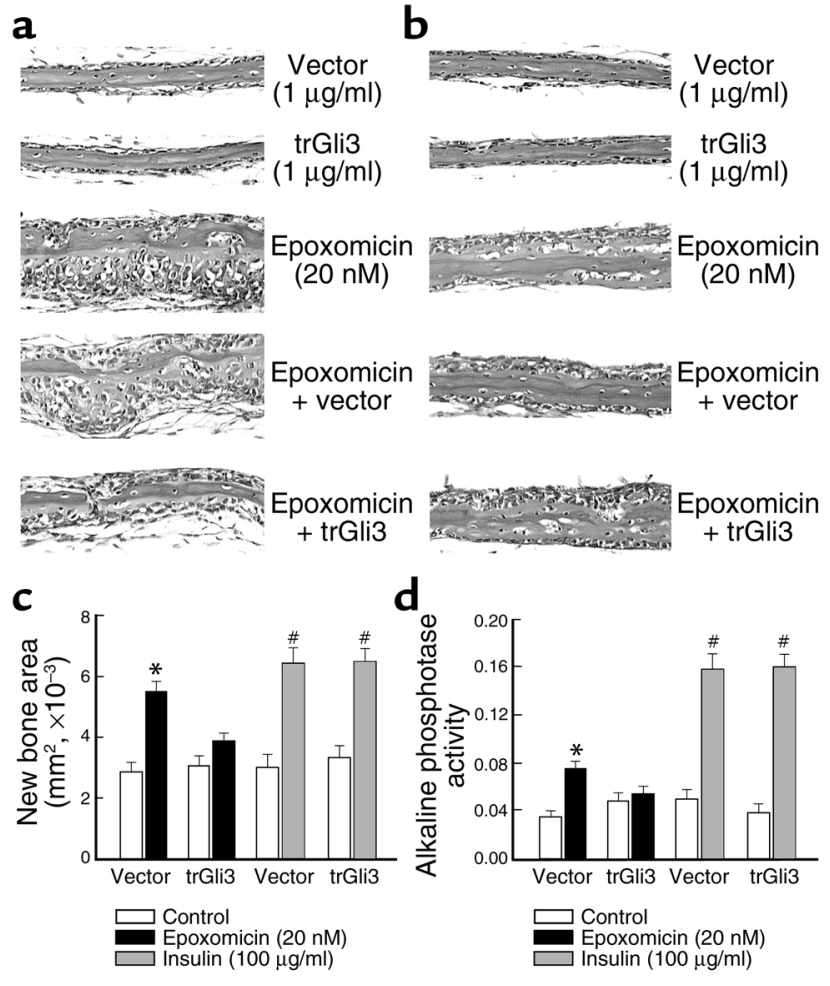

Figure 9

Calvarial tissues were transfected with empty vector or expression plasmid of trGli3 and treated with or without epoxomicin (20 nM) and insulin $(100 \mu \mathrm{g} / \mathrm{ml})$. Changes in new bone formation and ALP activity in the medium were examined. Expression of trGli3 completely abolished epoxomicin-induced new bone formation ( $\mathbf{a}$ and $\mathbf{c}$ ) and ALP activity (d). In contrast, expression of trGli3 had no significant effects on insulin-induced bone formation ( $b$ and $\mathbf{c}$ ) and ALP activity $(\mathbf{d}) .{ }^{*} P<0.05$, unpaired $t$ test, compared with the group without epoxomicin treatment. ${ }^{\#} P<0.05$, unpaired $t$ test, compared with the group without insulin treatment.

Fc molecule show that extracellular BMPs are responsible for the biological effects of proteasome inhibitors, since noggin is a BMP antagonist with high affinities to BMP-2, BMP-4, and BMP-7 ligands $(22,23)$. The results are consistent with the concept that BMP-2 expressed and released by osteoblasts exposed to inhibitors of the chymotrypsin-like activity of the proteasome acts in an autocrine manner on osteoblasts to further promote osteoblast differentiation.

There is a precedent for small-molecular-weight compounds enhancing BMP-2 transcription in osteoblasts and bone formation in vivo. Our previous experiments have shown that statins, which lower serum cholesterol and prevent heart attacks, increase specifically BMP-2 promoter activity and bone formation both in vitro and in vivo (11). Statins have been implicated previously as proteasome inhibitors (26), but we could not see effects of the statins on proteasomes isolated from mammalian osteoblasts at concentrations that stimulate bone formation (data not shown). Our current data suggest that statins increase BMP-2 promoter activity by their effects on small GTP-containing pro- teins, which in turn affect eNOS expression and ultimately BMP-2 promoter activity (27).

Our studies shed light on the mechanisms by which the proteasome inhibitors stimulate BMP-2 gene expression and bone formation. One possibility is suggested by the regulation of the $d p p$ gene, the fruit fly counterpart of the BMP-2 and -4 genes.

In Drosophila, the $d p p$ gene is regulated by the transcription factor $\mathrm{C} i$, the processing of which is proteasome dependent $(19,28-30)$. In mammalian cells, though Gli3, the homologue of $\mathrm{Ci}$, is also degraded in a proteasome-dependent manner, the effect of Gli3 on BMP-2 (the mammalian homologue of $d p p$ ) gene transcription has not been reported. We have found that the proteolytically processed $\mathrm{N}$-terminal fragment form of Gli3 (trGli3) is a potent repressor for BMP-2 gene transcription. By analyzing a series of deletion constructs of the BMP-2 promoter and mutating the putative Gli-binding sites, we identified the responsive elements for trGli3 in the BMP-2 promoter. Overexpression of trGli3 in osteoblast precursor cells completely abolished the effects of proteasome inhibitors on BMP-2 gene transcription, and transfection of trGli3 expression plasmid into calvarial tissues inhibited bone formation induced by proteasome inhibitors.

Proteasome inhibitors inhibit the proteolytic processing of Gli3 protein and prevent the production of the truncated form of Gli3. This prevents the suppression of BMP-2 gene transcription. Thus, the stimulatory activities of proteasome inhibitors on BMP-2 gene transcription may work, at least in part, by inhibiting the conversion of Gli3 precursor protein into trGli3, which represses BMP-2 gene transcription through binding to the specific responsive elements in BMP-2 promoter.

Inhibitors of the proteasome have been used recently to probe the role of intracellular proteolytic degradation in specific cellular processes and more recently as potential therapies in certain cancers (4). Recent reports show that one such agent, PS-341, reduced tumor growth in murine tumor models (31). The beneficial effect of proteasome inhibitors in cancer may be due to their inhibitory effects on mitotic cyclins that regulate cell division or by promotion of apoptosis through increased translocation of NF- $\mathrm{KB}$ to the nucleus, which is dependent on the degradation of $\mathrm{I}-\mathrm{\kappa B}$, a process controlled by the proteasome. Since PS-341 is not commercially available, the relative potencies of PS-341 in cancer cells and proteasome inhibitors used in the present studies in bone cells cannot be compared. Proteasome inhibitors PS1 (0.01-10 $\mu \mathrm{M}), \mathrm{MG}-132$ (1 and $10 \mu \mathrm{M})$, and lactacystin $(10 \mu \mathrm{M})$, however, have been shown to induce apoptosis in rat pituitary MMQ tumor cells. In rat pituitary GH3 tumor cells, PS1 (1 and $10 \mu \mathrm{M}), \mathrm{MG}-132(1$ and $10 \mu \mathrm{M})$, and lactacystin $(10 \mu \mathrm{M})$ also induced cell apoptosis (32). These concentrations of proteasome inhibitors are much greater compared with those used in our studies to stimulate bone formation. Further evaluation of proteasome 
inhibitors in vivo has shown that doses of PS1 as high as $50 \mathrm{mg} / \mathrm{kg}$ body weight given over a 5 -day period do not have any detrimental effects in mice.

In other studies to assess the potential toxicity of these compounds in vivo, and PS1 and epoxomicin in vivo, 20 and $50 \mathrm{mg} / \mathrm{kg} /$ day of PS1 and 1 and 5 $\mathrm{mg} / \mathrm{kg} /$ day of epoxomicin were injected subcutaneously in mice daily for 5 days. Heart, liver, lungs, kidney, and skin from the injection site showed that no abnormalities were observed by morphologic examination, either macroscopically or microscopically, and there was no morbidity or mortality. There were no effects on serum creatinine or other electrolytes or on peripheral blood counts. These results indicate that PS1 and epoxomicin are not toxic in vivo at the daily doses of 50 and $5 \mathrm{mg} / \mathrm{kg} /$ day for 5 days, respectively. This does not imply, however, that these compounds are necessarily potentially desirable therapies for chronic diseases such as osteoporosis. They do, however, indicate that they are useful research tools for pointing important molecular mechanisms that regulate osteoblast differentiation.

The proteasome is a $700-\mathrm{kDa}$, cylinder-shaped, multicatalytic protease complex composed of 28 subunits organized into four rings. In yeast and other eukaryotes, seven different $\beta$ subunits make up the inner rings. In addition to the ubiquitously expressed $\beta$ subunits, higher vertebrates also possess three IFN- $\gamma$ inducible $\beta$ subunits (LMP7, LMP2, and MECL1), which replace their normal counterparts, $X, Y$, and $Z$, respectively, thus altering the catalytic activities of the proteasome (33). Proteasome inhibitors are of multiple classes and chemical structures. For example, the peptide aldehydes are substrate analogues and transition state inhibitors, whereas lactacystin is a natural product of actinomycetes that covalently modifies the active site threonine of the $\beta$ subunit (34). The Streptomyces product epoxomicin and related analogues are selective inhibitors primarily of the chymotrypsin-like activity of the proteasome. Although most of these compounds such as the peptide aldehydes and lactacystin inhibit not only proteasome activity but also other nonproteasomal proteases, the streptomycetes-derived epoxyketone natural product epoxomicin and related analogues are irreversible inhibitors of specific proteasomal catalytic $\beta$ subunits with relative selectivity $(16,35,36)$. Our data suggest that compounds that inhibit the LMP7/X $\beta$ catalytic subunits of the osteoblast proteasome markedly enhance osteoblast differentiation and implicate these particular subunits as being important in the regulation of bone formation. If proteasome inhibitors were to become useful agents for the treatment of osteoporosis and related diseases, it would require their specificity for bone along with evidence of nontoxicity in other tissues. As noted above, potent proteasome inhibitors are now being used in patients with cancer in clinical trials, and they have shown relatively modest toxicity (31).
Patients with osteoporosis have severe bone loss associated with microarchitectural disturbance of trabecular bone and a tendency to fracture bones following trivial injury. Patients with advanced disease have lost more than $50 \%$ of bone mass at critical sites, such as the hip and vertebral spine. The most compelling therapeutic need in the osteoporosis field is an anabolic agent that will enhance new bone formation and restore bone that has been previously lost. Our data show that agents that target the ubiquitin-proteasome pathway may enhance bone formation by their effects to stimulate BMP-2 production. Since there are many potential sites of regulation in this pathway, these results suggest many potential molecular targets for future drug discovery for agents that enhance the formation of bone.

\section{Acknowledgments}

The authors express their gratitude to Alfred Goldberg for his critique of the manuscript and helpful suggestions and Shunsuke Ishii (RIKEN Tsukuba Institute, Tsukuba, Japan) for providing us with the Gli3 expression vector.

1. Hauschka, P.V., Mavrakos, A.E., Iafrati, M.D., Doleman, S.E., and Klagsbrun, M. 1986. Growth factors in bone matrix. Isolation of multiple types by affinity chromatography on heparin-Sepharose. J. Biol. Chem. 261:12665-12674.

2. Mundy, G.R., et al. 1995. The effects of cytokines and growth factors on osteoblastic cells. Bone. 17(Suppl.):71S-75S.

3. Pfeilschifter, J., and Mundy, G.R. 1987. Modulation of type beta transforming growth factor activity in bone cultures by osteotropic hormones. Proc. Natl. Acad. Sci. U. S. A. 84:2024-2028.

4. Kisselev, A.F., and Goldberg, A.L. 2001. Proteasome inhibitors: from research tools to drug candidates. Chem. Biol. 8:739-758.

5. Goldberg, A.L., Akopian, T.N., Kisselev, A.F., Lee, D.H., and Rohrwild, M. 1997. New insights into the mechanisms and importance of the proteasome in intracellular protein degradation. Biol. Chem. 378:131-140.

6. Goldberg, A.L., Elledge, S.J., and Harper, J.W. 2001. The cellular chamber of doom. Sci. Am. 284:68-73.

7. Sin, N., et al. 1999. Total synthesis of the potent proteasome inhibitor epoxomicin: a useful tool for understanding proteasome biology. Bioorg. Med. Chem. Lett. 9:2283-2288.

8. Sin, N., Meng, L., Auth, H., and Crews, C.M. 1998. Eponemycin analogues: syntheses and use as probes of angiogenesis. Bioorg. Med. Chem. 6:1209-1217.

9. Elofsson, M., Splittgerber, U., Myung, J., Mohan, R., and Crews, C.M. 1999. Towards subunit-specific proteasome inhibitors: synthesis and evaluation of peptide alpha',beta'-epoxyketones. Chem. Biol. 6:811-822.

10. Traianedes, K., Dallas, M.R., Garrett, I.R., Mundy, G.R., and Bonewald, L.F. 1998. 5-Lipoxygenase metabolites inhibit bone formation in vitro. Endocrinology. 139:3178-3184.

11. Mundy, G., et al. 1999. Stimulation of bone formation in vitro and in rodents by statins. Science. 286:1946-1949.

12. Dunstan, C.R., et al. 1999. Systemic administration of acidic fibroblast growth factor (FGF-1) prevents bone loss and increases new bone formation in ovariectomized rats. J. Bone Miner. Res. 14:953-959.

13. Ghosh-Choudhury, N., et al. 1996. Immortalized murine osteoblasts derived from BMP 2-T-antigen expressing transgenic mice. Endocrinology. 137:331-339.

14. Rock, K.L., et al. 1994. Inhibitors of the proteasome block the degradation of most cell proteins and the generation of peptides presented on MHC class I molecules. Cell. 78:761-771.

15. Dai, P., et al. 1999. Sonic Hedgehog-induced activation of the Gli1 promoter is mediated by GLI3. J. Biol. Chem. 274:8143-8152.

16. Meng, L., Kwok, B.H., Sin, N., and Crews, C.M. 1999. Eponemycin exerts its antitumor effect through the inhibition of proteasome function. Cancer Res. 59:2798-2801.

17. Palombella, V.J., Rando, O.J., Goldberg, A.L., and Maniatis, T. 1994. The ubiquitin-proteasome pathway is required for processing the NF-kappa B1 precursor protein and the activation of NF-kappa B. Cell. 78:773-785. 
18. Samuels, A., Perry, M.J., Gibson, R.L., and Tobias, J.H. 1999. The anabolic actions of estrogen and PTH on the murine skeleton are additive. J. Bone Miner. Res. 14:S452. (Abstr.)

19. Jiang, J., and Struhl, G. 1998. Regulation of the Hedgehog and Wingless signalling pathways by the F-box/WD40-repeat protein Slimb. Nature. 391:493-496.

20. Methot, N., and Basler, K. 1999. Hedgehog controls limb development by regulating the activities of distinct transcriptional activator and repressor forms of Cubitus interruptus. Cell. 96:819-831.

21. Muller, B., and Basler, K. 2000. The repressor and activator forms of Cubitus interruptus control Hedgehog target genes through common generic gli-binding sites. Development. 127:2999-3007.

22. Smith, W.C., and Harland, R.M. 1992. Expression cloning of noggin, a new dorsalizing factor localized to the Spemann organizer in Xenopus embryos. Cell. 70:829-840.

23. Brunet, L.J., McMahon, J.A., McMahon, A.P., and Harland, R.M. 1998. Noggin, cartilage morphogenesis, and joint formation in the mammalian skeleton. Science. 280:1455-1457.

24. Hui, C.C., and Joyner, A.L. 1993. A mouse model of greig cephalopolysyndactyly syndrome: the extra-toesJ mutation contains an intragenic deletion of the Gli3 gene. Nat. Genet. 3:241-246.

25. Harris, S.E., et al. 1994. Expression of bone morphogenetic protein messenger RNA in prolonged cultures of fetal rat calvarial cells. J. Bone Miner. Res. 9:389-394.

26. Rao, S., et al. 1999. Lovastatin-mediated G1 arrest is through inhibition of the proteasome, independent of hydroxymethyl glutaryl-CoA reductase. Proc. Natl. Acad. Sci. U. S. A. 96:7797-7802.

27. Garrett, I.R., et al. 2000. Statins mediate their effects on osteoblasts by inhibition of HMG-CoA reductase and ultimately BMP-2. J. Bone Miner. Res. 15:S225. (Abstr.)

28. Ingham, P.W. 1998. Transducing Hedgehog: the story so far. EMBO 17:3505-3511.

29. Chen, C.H., et al. 1999. Nuclear trafficking of Cubitus interruptus in the transcriptional regulation of Hedgehog target gene expression. Cell. 98:305-316.

30. Aza-Blanc, P., Ramirez-Weber, F.A., Laget, M.P., Schwartz, C., and Kornberg, T.B. 1997. Proteolysis that is inhibited by hedgehog targets Cubitus interruptus protein to the nucleus and converts it to a repressor. Cell. 89:1043-1053.

31. Adams, J., et al. 1999. Proteasome inhibitors: a novel class of potent and effective antitumor agents. Cancer Res. 59:2615-2622.

32. Yu, R., Ren, S.G., and Melmed, S. 2002. Proteasome inhibitors induce apoptosis in growth hormone- and prolactin-secreting rat pituitary tumor cells. J. Endocrinol. 174:379-386.

33. Driscoll, J., Brown, M.G., Finley, D., and Monaco, J.J. 1993. MHC-linked LMP gene products specifically alter peptidase activities of the proteasome. Nature. 365:262-264.

34. Fenteany, G., et al. 1995. Inhibition of proteasome activities and subunit-specific amino-terminal threonine modification by lactacystin. Science. 268:726-731.

35. Meng, L., et al. 1999. Epoxomicin, a potent and selective proteasome inhibitor, exhibits in vivo antiinflammatory activity. Proc. Natl. Acad. Sci. U. S. A. 96:10403-10408.

36. Groll, M., Koguchi, Y., Huber, R., and Kohno, J. 2001. Crystal structure of the 20S proteasome:TMC-95A complex: a non-covalent proteasome inhibitor. J. Mol. Biol. 311:543-548. 